\title{
Sampling Big Sagebrush for Phytomass
}

\section{W. URESK, R. O. GILBERT, AND W. H. RICKARD}

Highlight: A double sampling procedure was employed for obtaining more reliable weight estimates for leaves, flowering stalks, live wood, dead wood, various combinations of the preceding, and total phytomass of sagebrush shrubs. Easily obtained dimension measurements were related to harvest categories using regression analyses. Volume (length $x$ width $x$ height) and length measurements were the most highly correlated to phytomass. Double sampling reduced the variance of the mean phytomass estimates ranging from $33 \%$ to $80 \%$ for the various categories assuming optimum allocation. The precision achieved by combining dimension measurements with harvesting is significantly higher than by harvests without supporting dimensional measurements.

Efforts to obtain reliable phytomass estimates for rangeland shrubs by harvest methods are time consuming and costly. One approach is to establish a relationship between one or a few easily obtained plant measurements and harvest data. This approach has been termed double sampling or dimension analysis.

Aboveground phytomass has seldom been measured in desert shrubs. Harniss and Murray (1976) found a relationship between foliage of big sagebrush and the independent variables, circumference, and height of plant. A correlation $\left(R^{2}=0.93\right)$ was obtained with the developed dry weight predictor to determine total phytomass estimates of sagebrush. Chew and Chew (1965) determined shrub weights of creosotebush (Larrea divaricata) in Arizona, and Ludwig et al. (1975) used a double sampling method involving dimension analysis to estimatc phytomass on eight species of desert shrubs in New Mexico. The results show that volume and canopy area were generally suitable estimators. Medin (1960) used a crown diameterweight relationship to predict foliage phytomass in mountainmahogany (Cercocarpus montanus) shrubs on Colorado mule deer range. There appears to be little published data on phytomass sampling in big sagebrush (Artemisia tridentata) in the Pacific Northwest (Daubenmire 1970).

\footnotetext{
Authors are research scientist and senior research scientists, Battelle, Pacific Northwest Laboratories, Richland, Washington 99352.

Work was performed under contract EY-76-C-06-1830 with the U.S. Energy Research and Development Administration and National Science Foundation Grant GB-31862X2 to the Grassland Biome, U.S. International Biological Program for "Analysis of Structure, Function, and Utilization of Grassland Ecosystems.'

Thanks are extended to V. D. Charles and H. A. Sweany for their technical assistance in the field. Appreciation is expressed to C. A. Lee for hand separating the phytomass categories of big sagebrush.

Manuscript received August 28, 1976.
}

This paper presents the results of a double sampling pro cedure to obtain more reliable phytomass estimates of leave flowering stalks, live wood, leaves + live wood, dead woor live wood + dead wood, flowering stalks + leaves, miscellan ous fragments, and total phytomass for big sagebrush, the mo abundant shrubby species in the shrub-steppe region of soutl eastern Washington.

\section{Study Area and Methods}

The study site is located on the Arid Lands Ecology (ALE) Reser on the United States Energy Research and Development Administr tion's Hanford Reservation. Topographically, the site is located on tl low, east-facing slopes of the Rattlesnake Hills at an elevation of abo 1,300 feet above mean sea level. The vegetation of the area representative of the Artemisia tridentata/Agropyron spicatum assoc ation (Daubenmire 1970). Prior to the initiation of the study reports here, there had been little or no grazing by domestic livestock sin 1943 (Rickard et al. 1975).

In November 1974, a total of $20(n)$ big sagebrush shrubs we selected within a $300 \times 300$-m experimental pasture. The shrubs we not selected in a strictly random manner; instead, attempts were ma to obtain a sample of different sized shrubs varying from smallest largest. For each of the $\mathfrak{n}$ shrubs the following dimensions we measured: (1) longest diameter of the canopy, (2) longest diameter the canopy measured at right angles to the above dimension, and ( maximum heights. The individual shrubs were then cut off at grou level and oven-dried weights obtained for the following han separated categories: leaves, livewood, flowcring stalks, dead woo dead leaves, and miscellaneous parts. These dimensions were al: taken on all sagebrush shrubs $\left(n^{\prime}\right)$ rooted within eight $15 \times 30$-m plo located at random within the larger $300 \times 300-\mathrm{m}$ pasture.

The objective of this sampling design was to minimize the varian of the estimated mean phytomass for each category for a fixed cos The sampling procedure involved double sampling in conjunctic with linear regression (Cochran 1963, p. 327-354). Double samplir is a combination of two different methods for estimating phytomas (1) clipping, separating, and obtaining dry weights of total shrubs ar shrub parts, and (2) taking height, length, width, or volume (length width $\times$ height) dimension measurements on shrubs, including tho: harvested. Double sampling can be effective in reducing the varian of mcan phytomass estimates if the linear correlation $\rho$ betwer phytomass and dimension measurements is sufficiently near 1 , and the cost $\left(c_{n^{\prime}}\right)$ of making dimension measurements on a shrub is sul stantially less than the cost $\left(c_{n}\right)$ of clipping, drying, and weighin: Cochran's (1963) Figure 12.1 (page 338) gives the relation betwet $c_{n} / c_{n^{\prime}}$ and $\rho$ for fixed values of the relative precision of double ar single sampling. 
Dimension and oven-dry weight measurements were obtained for the $n$ clipped shrubs. These data were used to estimate a linear regression (calibration) equation relating phytomass (dependent variable) with all shrub dimensions (independent variable). A separate equation was estimated for each phytomass category. The additional information contained in the dimension measurements obtained on each of the $n^{\prime}$ shrubs within the eight $15 \times 30$-m plots were used in conjunction with the regression equation to estimate the mean phytomass per shrub $\left(\bar{Y}_{d s} ; d s\right.$ stands for $d$ ouble sampling) for each category. The equation is

$$
\tilde{Y}_{d s}=\bar{Y}_{n}+b\left(\bar{X}_{n^{\prime}}-\bar{X}_{n}\right)
$$

where $\bar{Y}_{n}$ is the mean phytomass per shrub based on the $n=20$ clipped shrubs, $\bar{X}_{n}$ is the mean volume of the 20 clipped shrubs, $b$ is the estimated slope of the regression of biomass per shrub on volume per shrub, and $\bar{X}_{n^{\prime}}$ is the mean volume per shrub of the $n^{\prime}=568$ shrubs in the eight plots. Volume was usually chosen as the independent variable because it generally had the highest estimated correlation $\hat{\rho}$ with all biomass categories.

The variance of $\bar{Y}_{d s}$ was estimated using the approximate formula

$$
\operatorname{Var}\left(\bar{Y}_{d s}\right)=S^{2} y \cdot x\left[\frac{1}{n}+\frac{\left(\bar{X}_{n^{\prime}}-\bar{X}_{n}\right)^{2}}{\sum_{i=1}^{20}\left(X_{i}-\bar{X}_{n}\right)^{2}}\right]+\frac{S^{2} y-S^{2} y \cdot x}{n^{\prime}}
$$

where $S^{2} y . x$ is the residual variance about the regression line, $S^{2} y$ is the variance of the 20 biomass data points,

$$
\sum_{i=1}^{20}\left(X_{i}-\bar{X}_{n}\right)^{2}
$$

is the sum of squared deviations of the 20 volume measurements from their mean $\bar{X}_{n}, n$ is the number of shrubs for which both biomass and volume measurements were made $(n=20)$, and $n^{\prime}$ is the number of shrubs for which only dimension measurements were taken $\left(n^{\prime}=\right.$ 568).

The average biomass per shrub $\bar{Y}_{d s}$ is multiplied by the average number of shrubs per square meter, $\bar{Z}$, to approximate $\bar{Y}$, the average biomass of sagebrush $/ \mathrm{m}^{2}$, i.e.,

$$
\bar{Y} \simeq \bar{Y}_{d s} \bar{Z}
$$

The standard error of $\bar{Y}$ is approximated by the following (Kempthorne and Allmorus 1965):

$$
[\operatorname{Var}(\bar{Y})]^{1 / 2}=\left[\bar{Z}^{2} \operatorname{Var}\left(\bar{Y}_{d s}\right)+\bar{Y}^{2} d s \operatorname{Var}(\bar{Z})\right]^{1 / 2}
$$

Double sampling is an effective technique if the variance of $\bar{Y}_{d s}$ is less than the variance of the mean biomass estimate $\bar{Y}_{S}$ (g/hush) that one would obtain if the entire effort had been devoted to clipping shrubs and obtaining dry weights, with total $\operatorname{cost} C$ remaining the same as for the double sampling procedure (see equation 7 for the assumed cost function). The ratio of $\operatorname{Var}\left(\bar{Y}_{d s}\right)$ to $\operatorname{Var}\left(\bar{Y}_{s}\right)$, assuming the optimum number of samples and $n^{\prime}$ were used in the double sampling scheme, can be estimated using the equation (Cochran 1963, pages 337-339):

$$
\frac{\operatorname{Var}\left(\bar{Y}_{d s(\mathrm{opt})}\right)}{\operatorname{Var}\left(\bar{Y}_{s}\right)}=\frac{V_{n}+V_{n^{\prime}} \frac{c_{n^{\prime}}}{c_{n}}+2 \sqrt{V_{n} V_{n^{\prime}} \frac{c_{n^{\prime}}}{c_{n}}}}{S^{2} y}
$$

where $V_{n}=S^{2} y \cdot x$ and $V_{n^{\prime}}=S^{2} y-S^{2} y \cdot x$
The optimum ratio of $n^{\prime}$ to $n$ can be estimated using

$$
\frac{n^{\prime}}{n}=\sqrt{\frac{V_{n^{\prime} c_{n}}}{V_{n} c_{n^{\prime}}}}
$$

as given by Cochran (1963, equation 12.9). For comparison purposes, we assumed that $c_{n} / c_{n}$ ' was equal to $120 / 1$, i.e., a clipped estimate of phytomass is 120 times as expensive to obtain as are the dimension measurements on a shrub.

The ratio $120: 1$ is appropriate if estimates on all plant parts are desired. If estimates on only a few or a single plant part are needed, the cost ratio would be smaller due to lower harvesting costs. To illustrate the effect of a lower ratio, we have computed equations 5 and 6 when an estimate of only total phytomass is needed, assuming a cost ratio of $10: 1$.

\section{Results and Discussion}

Dimension data were collected on 568 live and 275 dead shrubs (Table 1). These data showed that dead shrubs are smaller on the average for length, width, height, and volume (length $\times$ width $\times$ height). Shrub density was estimated at $2,342 \pm 246$ ( \pm SE) shrubs/ha of which $1,577 \pm 261$ and $765 \pm 100$ are live and dead, respectively. Dimension measurements obtained on the 20 clipped shrubs are given in Table 2 . The average dimension measurements in Table 2 tend to be greater than those in Table 1. Since these 20 shrubs were not chosen at random, there may have been a selection bias toward larger shrubs.

Phytomass estimates obtained via clipping and drying were highly correlated (linearly) with volume and length (Table 3 ). Various combinations of length, width, and height were correlated to the various phytomass categories. Only those that showed the highest correlations are presented here. For most categories, volume (length $\times$ width $\times$ height) had the highest correlation. In estimating phytomass, volume $(V)$ was chosen as the independent variable for all phytomass categories except for flowering stalks, and a miscellaneous category when the independent variable length was used. The $R^{2}$ (square of the linear correlation coefficient) values ranged from a low of 0.45 for miscellaneous to a high of 0.86 for total phytomass.

The estimates of phytomass obtained in this study using double sampling are presented in Table 4. Equation 1 was used to estimate the mean phytomass on a per-shrub basis. These were converted to $\mathrm{g} / \mathrm{m}^{2}$ using equation 3 . These results indicate that wood makes up approximately $62 \%$ of the total phytomass of sagebrush. Dead wood accounted for $11 \%$ of the phytomass, while leaves and floral parts made up 14 and $8 \%$ of the total, respectively. Total phytomass of sagebrush was estimated to be $69 \mathrm{~g} / \mathrm{m}^{2}$.

Double sampling has apparently reduced the variance associated with mean phytomass values. This occurred because of the high cost ratio $(\simeq 120: 1)$ and the good correlation between phytomass estimates $(Y)$ and dimension measurements $(X)$. Table 5 shows that reduction in the variance of the phytomass estimates ranged from 33 to $80 \%$ for the various categories. Hence, it appears that double sampling as used here was effective in obtaining more precise estimates of sagebrush phytomass than would have been the case if only harvesting had been employed.

When estimating total phytomass only and not considering the cost of separating it to the various categories, a reduction in variance of $56 \%$ was estimated assuming a cost ratio of 10:1 (Table 5). These results show that double sampling was more effective than harvesting shrubs alone to obtain total phytomass of big sagebrush. 
Table 1. Dimension measurements (cm) of live and dead sagebrush shrubs.

\begin{tabular}{|c|c|c|c|c|c|c|}
\hline \multirow[b]{2}{*}{ Dimension } & \multicolumn{3}{|c|}{ Dead $(n=275)$} & \multicolumn{3}{|c|}{ Live $(n=568)$} \\
\hline & $\bar{X} \pm S E$ & Range & $C V^{1}$ & $\bar{X} \pm S E$ & Range & $\mathrm{CV}$ \\
\hline Length & $53 \pm 1.2$ & $10-128$ & 37 & $71 \pm 1.2$ & $14-199$ & 41 \\
\hline Width & $35 \pm 0.9$ & $10-88$ & 42 & $48 \pm 0.9$ & $10-131$ & 45 \\
\hline Height & $36 \pm 0.7$ & $12-73$ & 31 & $49 \pm 0.8$ & $12-117$ & 41 \\
\hline Volume ${ }^{2}$ & $86248 \pm 5796$ & $2310-739200$ & 111 & $238848 \pm 12817$ & $2880-2190384$ & 128 \\
\hline
\end{tabular}

${ }^{1}$ Coefficient of variation $=(S E \times \sqrt{n} / \bar{X}) \times 100$.

2 Volume $\left(\mathrm{cm}^{3}\right)=$ length $\times$ width $\times$ height.

Table 2. Dimension measurements $(\mathrm{cm})$ for 20 live sagebrush shrubs.

\begin{tabular}{lccc}
\hline Dimension & $\bar{X} \pm S E$ & Range & $C V^{1}$ \\
\hline Length & $86 \pm 8$ & $30-185$ & 39 \\
Width & $68 \pm 6$ & $27-142$ & 39 \\
Height & $70 \pm 5$ & $28-104$ & 31 \\
Volume $^{2}$ & $536500 \pm 134403$ & $22680-2732100$ & 112 \\
\hline
\end{tabular}

${ }^{1}$ Coefficient of variation $=(S E \times \sqrt{n} / \hat{X}) \times 100$.

"Volume $\left(\mathrm{cm}^{3}\right)=$ length $\times$ width $\times$ height.

Table 3. Estimated regression equations for estimating phytomass (g/ shrub) using volume $(V)$ measurements (length $x$ width $\times$ height) or length ( $L)$.

\begin{tabular}{|c|c|c|c|}
\hline Dependent variable & Est & timated equation & $R^{2}$ \\
\hline Leaves & $\hat{Y} d s$ & $=43+0.0000907 \mathrm{~V}$ & $.68 * *$ \\
\hline Live wood & $\hat{Y}_{d s}$ & $=128+0.000603 \mathrm{~V}$ & $.80^{* *}$ \\
\hline Leaves + live wood & $\hat{Y}_{d s}$ & $=171+0.00694 \mathrm{~V}$ & $.82 * *$ \\
\hline Flowering stalks & $\hat{Y}_{d s}$ & $=-128+2.269 \mathrm{~L}$ & $.52 * *$ \\
\hline Dead wood & $\hat{Y}_{d s}$ & $=-26+0.000197 \mathrm{~V}$ & $.80 * *$ \\
\hline Live wood + dead wood & $\hat{Y}_{d s}^{\operatorname{cs}}$ & $=128+0.000811 \mathrm{~V}$ & $.77 * *$ \\
\hline Flowering stalks + leaves & $\hat{Y}_{d s}$ & $=59+0.000193 \mathrm{~V}$ & $.66^{* *}$ \\
\hline Miscellaneous & $\hat{Y}_{d s}$ & $=-11+0.348 \mathrm{~L}$ & $.45 * *$ \\
\hline Total phytomass & $\hat{Y}_{d s}^{w 0}$ & $=196+0.00102 \mathrm{~V}$ & $.86^{* *}$ \\
\hline
\end{tabular}

**Significant at $\alpha \leq 0.01$.

Table 4. Estimated average phytomass of sagebrush using double sampling.

\begin{tabular}{lccc}
\hline \hline Dependent variable & $n^{1}$ & $\mathrm{~g} /$ shrub $\pm S E \dagger$ & $\mathrm{g} / \mathrm{m}^{2} \pm S E \dagger \dagger$ \\
\hline Leaves & 20 & $65 \pm 10$ & $10 \pm 2$ \\
Live wood & 20 & $272 \pm 48$ & $43 \pm 10$ \\
Leaves + live wood & 20 & $337 \pm 53$ & $53 \pm 12$ \\
Flowering stalks & 19 & $33 \pm 19$ & $5 \pm 3$ \\
Dead wood & 19 & $49 \pm 40$ & $8 \pm 7$ \\
Live wood + dead wood & 20 & $322 \pm 72$ & $51 \pm 14$ \\
Flowering stalks + leaves & 20 & $105 \pm 22$ & $16 \pm 4$ \\
Miscellaneous & 20 & $13 \pm 3$ & $2 \pm 1$ \\
Total phytomass & 20 & $440 \pm 70$ & $69 \pm 16$
\end{tabular}

${ }^{1} n=$ clipped shrubs + dimension measurements; $n^{\prime}=568$ plants for dimension measurements only.

t Obtained using equations (1) and (2)

† Obtained using equations (3) and (4).

For the fixed cost ratio $c_{n}: c_{n^{\prime}}=120: 1$, the ratio $n^{\prime}: n$ of sample sizes is presented in Table 5. The ratio ranges from $28: 1$ to $10: 1$ for the various tissue categories. The various categories with lower ratios require a greater proportion of clipped plots. For example (assuming $c_{n}=c_{n}$ for the moment), if one examines a total of 100 shrubs, a ratio of 10:1 indicates about 9 shrubs would be clipped (dimension measurements also being taken), and 91 shrubs would be measured for dimensions only. Having a ratio of 20:1 would reduce the clipped number of shrubs by approximately one-half (to about 5) while increasing to 95 the number of shrubs where only dimension measurements are taken.

In double sampling, cost is a major factor to consider. Once this has been determined, then the number of samples $n$ (clipped
Table 5. Estimated optimum ratio $n^{\prime}: n$ of sample sizes and the estimated reduction in variance obtained using double sampling assuming a cost ratio of 120:1.

\begin{tabular}{lcc}
\hline Category & $\begin{array}{c}\text { Estimated optimum } \\
\text { ratio } n^{\prime}: n^{1}\end{array}$ & $\begin{array}{c}\text { Reduction in variance } \\
(\%) \text { under optimum } \\
\text { allocation }\end{array}$ \\
\hline Leaves & $16: 1$ & 58 \\
Live wood & $23: 1$ & 73 \\
Leaves + live wood & $24: 1$ & 75 \\
Flowering stalks & $12: 1$ & 42 \\
Dead wood & $10: 1$ & 33 \\
Live wood + dead wood & $21: 1$ & 69 \\
Flowering stalks + leaves & $16: 1$ & 56 \\
Miscellancous & $10: 1$ & 35 \\
Total phytomass & $28: 1$ & 80 \\
Total phytomass & $8: 1$ & 56 \\
\hline
\end{tabular}

1 Obtained using equation (6).

' Obtained using equation (5)

Assuming a cost ratio of 10:1

+ dimension measurements) and $n^{\prime}$ (only dimension measurements taken) can be determined if some prior knowledge of these parameters is known. Cochran (1963) considers the case where the cost of the two samples is

$$
C=n c_{n}+n^{\prime} c_{n^{\prime}}
$$

where $C$ is the total cost and $c_{n}$ and $c_{n^{\prime}}$ are the costs of obtaining clipped and dimension measurements, respectively. If we assume the total cost $C$ to be $\$ 1,000$ and $c_{n}: c_{n^{\prime}}=120: 1$ as outlined earlier and using the optimum ratio for the total phytomass $\left(n^{\prime}: n\right)$ of $28: 1$, then sample sizes for $n$ and $n^{\prime}$ can be determined.

From equation 7 we have that

$$
\$ 1,000=120 n+n^{\prime} .
$$

From the optimum ratio we obtain

$$
n^{\prime}=28 n \text {. }
$$

By substituting for $n^{\prime}$ we obtain

$$
\$ 1,000=120 n+28 n \text {, or }
$$

$$
n=6.8 \text {. }
$$

$$
\begin{aligned}
& \text { Solving of } n^{\prime} \\
& \quad \$ 1,000=120(6.8)+n^{\prime} \text {, or } \\
& n^{\prime}=184 .
\end{aligned}
$$

Assuming a cost of $\$ 1,000$, one would clip and take dimension measurements of 7 shrubs plus obtain dimension measurements of 184 shrubs.

Concerning the design of future sampling plans for estimating sagebrush phytomass, we see from Table 5 that the optimum ratio $n^{\prime}: n$ differs for each plant part. This occurs due to changes in $V_{n}$ and $V_{n^{\prime}}$ (equation 6) since $c_{n}: c_{n^{\prime}}$ was held constant at 120:1. Hence, the optimum $n$ and $n^{\prime}$ will vary for each plant part. This suggests that when planning a double sampling study with several variables (plant parts), it will not be possible to obtain the maximum reduction in variance for all variables simultaneously. One approach is to use the $n$ and $n^{\prime}$ that will achieve the maximum reduction in variance for the most 
important variable (perhaps total phytomass). More generally, $n$ and $n^{\prime}$ could be estimated for each plant part and a compromise made based on the relative importance of achieving maximum reduction in variance for the plant parts.

Also note from equation (2) that $\operatorname{Var}\left(\bar{Y}_{d s}\right)$ can be reduced if $\bar{X}_{n}$ and $\bar{X}_{n^{\prime}}$ (the mean dimension measurements on the $n$ and $n^{\prime}$ shrubs, respectively) are in close agreement. In these data, the two means are rather far apart (Tables 1 and 2), which may be due to a biased selection process for the 20 shrubs. This bias might have been less had the 20 shrubs been selected by using some kind of a random selection process. However, we also note that the variance of double sampling will decrease if

$$
\sum_{i=1}^{20}\left(X_{i}-\bar{X}_{n}\right)^{2}
$$

is large, i.e., if small as well as large shrubs are included in the 20 selected shrubs. By random selection of shrubs for clipping and volume measurements, we would have to take whatever shrubs were randomly selected so that a large sum of squared deviations would not necessarily result. One approach to this problem would be to divide the population of shrubs into nonoverlapping size categories and obtain random samples from each group.

The data examined here suggest that double sampling can be an effective technique in reducing the variance of the mean phytomass estimates of the various phytomass categories of big sagebrush. The precision achieved by combining dimension analysis with clipping and harvesting is significantly higher than by only harvesting shrubs when cost is held constant.

One of the major benefits of this double sampling procedure is that it is nondestructive when determining phytomass estimates of the various categories of sagebrush. Once a relation ship between clipped shrub values and dimension measurements has been established, then repeated phytomass inventories may be conducted on various sites by obtaining dimension measurements only, assuming the calibration relationship does not change.

\section{Literature Cited}

Chew, R. M., and A. E. Chew. 1965. The primary productivity of a desertshrub (Larrea tridentata) community. Ecol. Monogr. 35:355-375.

Cochran, W. G. 1963. Sampling techniques. John Wiley and Sons, Inc., New York. 413 p.

Daubenmire, R. 1970. Steppe vegetation of Washington. Wash. Agr. Exp Sta. Tech. Bull. 62. 131 p.

Harniss, R. O., and R. B. Murray. 1976. Reducing bias in dry leaf weight estimates of big sagebrush. J. Range Manage. 29:430-432.

Kempthorne, O., and R. R. Allmaras. 1965. Errors of observation. In Methods of Soil Analysis, Part 1. (Black, ed.). Amer. Soc. Agr. Inc., Madison, Wisc.

Ludwig, J. A., J. F. Reynolds, and P. D. Whitson. 1975. Size-biomass relationships of several Chihuahuan Desert shrubs. Amer. Midland Natur. 94:451-461.

Medin, D. E. 1960. Physical site factors influencing annual production of true mountain mahogany, Cercocarpus montanus. Ecology 41:454-460.

Rickard, W. H., D. W. Uresk, and J. F. Cline. 1975. Impact of cattle grazing on three perennial grasses in southcentral Washington. J. Range Manage. 28:108-112. 


\section{THESIS: OREGON STATE UNIVERSITY}

\section{Responses of Vegetation and Sheep to Three Grazing Pressures, by Frank Oren Thetford, Jr., PhD, Rangeland Resources, 1975.}

A study was conducted over a 2-year period, 1973 through 1974, on perennial ryegrass-subclover pastures with stocking rates of 7.4 (moderate), 9.9 (heavy), and 12.4 (overstocked) ewes per hectare to establish guidelines on stocking intensity for dryland improved pastures in western Oregon. Climatic conditions varied annually and caused variation in growth of the vegetation and differences in stocking dates among treatments. Grazing significantly depressed total forage yields in each year. However, there was no significant difference noted between years for total forage yields. Ryegrass yields remained the same for both years in all treatments. The yield of other grasses (primarily annuals) increased in heavily stocked and overstocked treatments during the period of this study, but not in the moderately stocked pastures. Moderately stocked pastures had more ryegrass available per head per day than the other treatments in all seasons. Nutritive value of the herbage followed normal seasonal trends. Herbage in 1974 was of lower nutritive value than in 1973. Animals in moderately stocked pastures were able to obtain sufficient forage of good quality to meet or exceed dry matter intake, protein, and energy requirements throughout both years. The data indicated that during the fall (1973) and summers $(1973,1974)$ diets of animals from overstocked pastures were deficient in dry matter intake, crude protein, and digestible energy. Digestibility of dry matter in the diets increased from $77 \%$ both years in early spring to 55\% during the summers; also, there was no difference among treatments. Annually, during early spring ewes on all treatments gained weight at the same rate. Ewes from moderately stocked pastures lost the least weight in the summer; ewes on the overstocked treatment lost the most. Weight gains of ewes and lambs were higher in 1973 than in 1974. There were no significant differences among treatments for the rate of gain of lambs. Likewise, no noticeable differences were observed in the total number of lambs born on each treatment. The results from the heavily stocked treatment were highly variable and sometimes they were similar to either the moderate or the overstocked treatment. Therefore, data indicate that 7.4 ewes per hectare may be the proper spring through fall stocking rate for these pastures. 